\title{
Venue of Mixed Actions in California
}

\author{
Arvo Van Alstyne*
}

The somewhat surprising volume of appellate court cases which involve the grant or denial of a motion for change of venue ${ }^{1}$ attests to the importance which, from a practical standpoint, is attached to the selection of place of trial. At first blush, in these days of high-speed transportation, a mere dispute over venue would hardly seem to be worth the time, legal energy, and expense entailed in the prosecution of an appeal. However, putting to one side the (probably) small percentage of cases in which mere delay is the chief motivating factor, the apparently felt need to litigate the venue issue to the highest appellate level illustrates the practical consequences which place of trial is deemed to have upon the ultimate substantive determination. Minimization of one's own and maximization of opposition expense and inconvenience; advantages of trial im familiar surroundings in the presence of known judicial personnel; availability of compulsory process, thereby securing the greater effectiveness of "live" testimony as compared with deposition evidence-these and other like considerations provide a partial explanation for the prevalence of reported venue decisions.

Practical considerations, however, provide at best only an explanation and not a reason. As a procedural matter, venue, which does not directly relate to substantive rights, should be ascertainable with a degree of simphicity which would justify assurance that the place of trial selected is indeed one authorized by statute. The primary criteria for satisfactory rules of venue would seem to be simplicity and fairness. Unfortunately, in an effort to achieve fairness Califorma has substituted for simplicity a complexity of statutory venue provisions and accompanying judicial gloss which has invited rather than discouraged litigation. ${ }^{2}$

* Professor of Law, University of California, Los Angeles.

1 In the six year period from January 1, 1950 to January 1, 1956, a total of 77 final appellate decisions involving venue issues were reported in California. Nine of these cases were decided by the supreme court and 68 by the district courts of appeal. Since all 9 of the supreme court opinions were preceded by decisions, later vacated on grant of hearing, by district courts of appeal, the total number of appellate opinions rendered was 86 . On the average, therefore, the appellate judiciary were required to prepare and file a venue opinion every twenty-five days.

2 Reliable standards in selection of venue are, of course, a necessity for both plaintifi and defendant. Where alternative venue choices are available, the plaintiff's selection, if a proper one, is binding, at least in the absence of a showing of local prejudice or inconvenience to witnesses. Cax. Code Crv. Proc. $\$ 397$. Defendant may not insist upon transfer to another equally proper alternative place of trial. Shulzmer Watch Co. v. Cortal, 130 Cal. App. 2d 901, 280 P.2d 228 (App. Dep't 1955). By the same token, where venue is improperly laid by plaimtiff, defendant's motion to transfer is denied unless the transferee county designated in the motion is one which is a proper court for trial. Beutke v. American Securities Co., 132 Cal. App. 2d 354, 282 P.2d 201 (1955); Sausen v. Anderton, 129 Cal. App. 2d 324, 276 P.2d 814 (1954). 
In broad outline it may be said that California constitutional and statutory provisions postulate choice of place of trial upon either (or both) of two general factors: the subject matter of the action ${ }^{3}$ and the nature of the parties named in the complaint. ${ }^{4}$ Disparity of treatment is not accidental but is the outgrowth of considered legislative efforts to strike a fair balance between the venue rights of plaintiffs and defendants. Section 392 of the Code of Civil Procedure, which confines venue of real property actions to the situs county, was conceived in the light of the same policy considerations which motivated adoption of the venue clause of section 5 of article VI of the 1879 constitution: ${ }^{5}$ to protect the real property owner from having to defend his title or right to possession in a court far removed from the situs thereof. ${ }^{6}$ Special venue treatment of corporate defendants ${ }^{7}$ was felt to be desirable in order to permit plaintiffs to lay venue where their dealings with the corporation had taken place rather than at the corporation's "residence," a county often remote from the scene of its business activities. ${ }^{8}$

${ }^{3}$ CAI. CODE Crv. Proc. $\$ \S 392$ (actions involving real property), 393 (actions to recover statutory penalty or forfeiture, 395 (actions involving injury to person or personal property, contract actions, and "all other cases").

${ }^{4}$ CAL. Const. art. XII, $\$ 16$ (actions against corporations and associations); CAL. CODE Crv. Proc. $\$ \S 393$ (actions against public officers), 394 (actions by or against a city or county), 395 (non-resident defendants), 395.1 (personal representatives as defendants), 401 (actions by or against state or its agencies).

${ }^{5}$ CAI. ConST. art. VI, $\S 5(1879)$ provides in part that "all actions for the recovery of the possession of, quieting title to, or for the enforcement of liens upon real estate, shall be commenced in the county in which the real estate, or any part thereof, affected by such action or actions, is situated." This provision is regarded as jurisdictional. Rogers v. Cady, 104 Cal. 288, 38 Pac. 81 (1894) ; Fritts v. Camp, 94 Cal. 393, 29 Pac. 867 (1892); Rice v. Schubert, 101 Cal. App. 2d 638, 226 P.2d 50 (1951).

${ }^{6}$ The advocates of the constitutional provision pointed to the concentration of corporate legal residences in San Francisco and to the fact that "a large proportion of the real property [in the state] is owned or controlled by the twenty thousand corporations of the state" as the reason for their proposal. Without a rule of venue embodied in the constitution, mere statutes requiring situs-venue of real property actions might be repealed, in which case "all the actions for the foreclosure of mortgages on real property throughout the State would be brought in San Francisco." 3 Debates and Proceedings of the Constitutionar Convention 1334 (1881).

7 CaI. Const. art. XII, \& 16. See note 90 infra.

8 One of the proponents of the constitutional corporation venue provision explained his purpose thusly: "Under our system, corporations have a legal residence at their principal place of business. The result is that corporations in this State are legally resident, nearly all of them, at the City and County of San Francisco, and that under our rules of practice, those who have litigation with such corporations must go to the City and County of San Francisco to sue .... That operates unjustly and unfairly. I think that the rule ought to be, that a person having a a cause of action against a corporation should be entitled to meet at the place where the cause of action has arisen, where the obligation or liability arises, or the breach occurs." 1 DEBATES and Proceedings of tae Constitutional Convention 452-53 (1881). Accordingly, the venue alternatives to the corporate principal place of business, authorized by section 16, have been held to be a plaintiff's privilege only and not a right upon which the corporate defendant may insist. Beutke v. American Securities Co., 132 Cal. App. 2d 354, 282 P.2d 201 (1955). See also Strassburger v. Santa Fe Land Improvement Co., 54 Cal. App. 7, 200 Pac. 1065 (1921); Fresno National Bank v. Superior Court, 83 Cal. 491, 24 Pac. 157 (1890). 
The 1911 amendment ${ }^{9}$ which authorized the county in which the injury occurred as an alternative to residence venue in personal injury and personal property damage actions reflected the increasing volume of automobile accident litigation and the desirability of permitting a local forum to the injured plaintiff in his action against the motorist from a distant county. ${ }^{10}$ Finally, the relatively recent provisions enlarging venue in contract actions ${ }^{11}$ undoubtedly were designed to give recognition to the increasing mobility of modern commercial practices in which residence of the parties to a business transaction is often less significant, from the viewpoint of business convenience, than place of execution or performance.

Problems of considerable complexity are involved in the normal interpretation of many of the specific venue provisions just cited. ${ }^{12}$ Moreover, such interpretative difficulties are greatly enhanced wlien, pursuant to the modern liberal rules regarding joinder of causes and parties, ${ }^{13}$ two or more causes of action, each of which is governed by different venue rules, are joined together, ${ }^{14}$ or the plaintiff names two or more defendants, each of whom is susceptible to a different venue standard. ${ }^{15}$ Cases of this type may be classified generically as involving the problem of "mixed actions." Their identifying characteristic is the ostensible concurrent applicability of two or more inconsistent venue provisions of the code or constitution.

\footnotetext{
${ }^{9}$ Cal. Stat. 1911, c. 421, § 1; CaI. Code Crv. Proc. \$ 395.
}

${ }^{10}$ See Monk v. Ehret, 192 Cal. 186, 219 Pac. 452 (1923) ; Graham v. Mixon, 177 Cal. 88, 169 Pac. 1003 (1917) ; Rains v. Diamond Match Co., 171 Cal. 326, 153 Pac. 239 (1915); Lucas v. Lucas Ranching Co., 18 Cal. App. 2d 453, 64 P.2d 160 (1937).

11 Cal. Stat. 1939, c. 981, \&1. This section deleted a three-hundred-dollars-in-controversy limitation previously applicable. See The Work of the 1939 California Legislature, 13 So. Carre. L. REv. 1, 12-13 (1939).

12 See generally 1 Witkra, CaIIfornda Procedure 699-749 (1954).

13 Previous requirements of homogeneity of cause of action as a condition of joinder of causes was greatly relased by the 1907 amendment of Code of Civil Procedure, section 427, permitting joinder of "claims arising out of the same transaction, or transactions connected with the same subject of action ... ." Cal. Stat. 1907, c. 372, $\$ 1$. Further liberalizing resulted from the 1927 code requirements for joinder of parties (see Cax. CodE Crv. Proc. $\$ 378$, as amended by Cal. Stat. 1927, c. 386, § 1; CaL. Code Crv. Proc. \$§ 379a, 379b, 379c, as added by Cal. Stat. 1927 , es. 259,260 , and 387 , respectively) and by virtue of subsequent judicial decision, which held that in cases of inconsistency the more recent (and more liberal) provisions for joinder of parties were deemed to prevail over the earlier joinder of causes requirements. Peters v. Bigelow, 137 Cal. App. 135, 30 P.2d 450 (1934); Kraft v. Smith, 24 Cal. 2d 124, 148 P.2d 23 (1944).

14 Despite the prevalence of mised actions, the requirement contained in CAx. CoDE Crv. Proc. $\$ 427$ that the "causes 50 united inust ... not require different places of trial" has never been invoked in any reported decision as a ground for declaring a misjoinder although it has been suggested as applicable. Weyer v. Weyer, $40 \mathrm{Cal}$. App. 765, 767, 182 Pac. 776, 777 (1919). It has been suggested that the requirement is procedurally unenforceable since a demurrer for misjoinder cannot be reached until any venue objections which defendant may wish to assert have either been sustained by a transfer to a proper county or waived by failure to make timely objection. Note, U.C.L.A. INTRA. L. Rev. 82 (1952).

15 See, e.g., Young v. John Haar Pickle Co., 139 Cal. App. 2d 534, 293 P.2d 796 (1956); Pacific Bal Industries v. Northern Timber, Inc., 118 Cal. App. 2d 815, 259 P.2d 465 (1953). 
A court faced with a "mixed action" problem would appear to have four basic avenues of solution: (1) to accord to the plaintiff a right of election whether to proceed under one venue provision or under the other, upholding his choice of venue if under either it would be regarded as proper; (2) to permit the defendant to exercise an election whether to insist upon venue under one provision or under the other; (3) to subordinate one of the conflicting venue provisions to the other, upon some basis either rational or arbitrary; or (4) to attempt a reconciliation or compromise between the conflicting provisions in such a way as to preserve, insofar as possible, the fundamental policy of both.

The California "mixed action" cases contain elements of all four of these potential solutions. Although the first approacli appears to have been completely rejected ${ }^{16}$ the remaining three have been accepted in varying degrees.

It is the purpose of the present study to attempt to analyze the California "mixed action" cases with a view to developing the theoretical foundations upon which solution of the venue problem las been predicated. The study, it is believed, will disclose that one of the clief characteristics of the nixed action venue cases is the wide divergence of theoretical approach employed in their solution. Such inconsistency in theory, furthernore, is not merely of academic interest for in a large variety of potential "mixed action" cases which have not yet found their way into the reported decisions the ultimate choice of proper venue may differ markedly depending upon the selection of theoretical approacli to be employed in solution of the problem presented. Accordingly, the strengths and weaknesses of each approach should be of some interest to the authors of both briefs and opinions.

Preliminarily, it may be observed that despite wide theoretical differerences which are potentially capable of leading to conpletely divergent results in specific instances, the conclusions reached in many of the "mixed action" cases which have actually been considered by the courts appear to be equally supportable regardless of the theoretical approacli actually invoked by the court. Such consistency of conclusion in the face of heterogeneity of theory suggests the possibility of formulating a general principle to reconcile the superficially inconsistent opmions. Such a principle may well provide a new approach to disposition of mixed action venue problems possessing the simplicity and reliability which ought to inhere in a rule of venue. A reconciliatory principle along these lines is proposed at the conclusion of the present study.

${ }^{16}$ See Ward Mfg. Co. v. Miley, 131 Cal. App. 2d 603, 605, 281 P.2d 343, 345 (1955); cf. Neet v. Holmes, 19 Cal. 2d 605, 612, 122 P.2d 557, 560 (1942); Sanborn v. Pomona Pump Co., 131 Cal. App. 241, 244, 21 P.2d 124, 126 (1933). 


\section{TERMTNOLOGY}

Consideration of the problem at hand is hampered to some extent by a lack of accepted terminology. The term "mixed action" is sometimes employed to refer to the combination in a single complaint of a cause of action which is "local" with one which is "transitory." Although this appellation may serve to identify the most frequently encountered problem of the type which we propose to discuss, it is etymologically broad enough to embrace joinder of other causes governed by disparate venue provisions and is thus ambiguous. Accordingly, it is believed that clarity of thought may be promoted by suggesting a sub-classification which may serve more accurately to distinguish the typical situations which arise in the cases.

1. Localmixed actions. This phrase will be used to refer to an action in which the plaintiff joins a cause of action involving real property within the meaning of section 392 of the Code of Civil Procedure ${ }^{17}$ with a cause of action the proper county for trial of which being governed by the provisions of section 395.18

2. Transitory-mixed actions. This term refers to the joinder in a single action of one count governed by section 395 with another count also governed by section 395. Although venue may be laid under section 395 in the county of a defendant's residence regardless of the nature of the cause of action, a non-residence county, e.g., the county where the injury occurred, or where the contract was entered into, etc., may also be a proper alternative place of trial of one or both counts. The "transitory-mixed action" is thus one in which the alternative choices of venue under the several transitory counts of the complaint are not identical.

17 See text at note 5 supra.

18 CaI. Code CIv. Proc. $\S 395$ governs the venue of three distinct types of causes of action: tort actions involving physical injury to person or personal property, in which proper venue is either where the injury occurs or the county in which one of the defendants resides at the commenceinent of the action; actions founded on the obhigation of a contract, in which proper venue is appropriate either in the county where the contract was entered into or the county in which one of the defendants resides at the commencement of the action, there being an occasional possibility that a third county may be appropriate; and, finally, "all other cases," as to which venue is appropriate only in the county in which one of the defendants resides at the commencement of the action.

Although the contract clause of $\$ 395$ authorizes venue in the county where the contract is entered into or is to be performed, as well as at defendant's residence, it further provides that the county in which the obligation sued upon "is incurred shall be deemed to be the county in which it is to be performed unless there is a special contract in writing to the contrary." Thus, in the absence of such special written stipulation, venue is normally proper only in the county where defendant resides or where the contract is entered into-since that is where the obhgation is normally incurred. Hale v. Bohannon, 38 Cal. 2d 458, 241 P.2d 4 (1952). A third county is proper only where expressly stipulated in writing as the county of performance, Armstrong v. Smith, 49 Cal. App. 2d 528, 122 P.2d 115 (1942), or where the obhigation is incurred elsewhere than the county in which the contract is entered into, Limited Mut. Compensation Ins Co. v. Curtis, 45 Cal. App. 2d 507, 114 P.2d 404 (1941). 
3. Corporation-mixed actions. This term will be used to identify cases in which the complaint names as defendants both a corporation and a private individual. Since the rules of venue which are applicable to the corporation are in many instances quite different from those which would be apphicable to the private individual defendant, both in contract ${ }^{10}$ and in tort $^{20}$ actions, a potential conflict of venue rules is often encountered in such cases.

4. Miscellaneous-mixed actions. In this category we lump, for convenience, all instances of joined causes of action governed by inconsistent venue provisions other than those embraced in the previous three categories. The category, for example, would include a case in which plaintiff joins a cause of action for the recovery of a statutory penaliy which is triable in the county in which the cause of action arose ${ }^{21}$ with a cause of action seeking to recover common law damages based on the same event, which cause of action would normally be triable in a county designated as proper by section 395.

The foregoing classifications are, of course, useful only to identily the simplest types of mixed action situations. Other permutations and combinations are clearly possible such as an overlapping of two or more of the foregoing categories. It is perfectly conceivable that in an ordinary lawsuit there may be a combination of counts which could be classified as involving a local-mixed venue problem while at the same time there might also be several transitory counts joined logether which pose a transitory-mixed problem. By the same token, in a corporation-mixed action one frequently encounters a combination of causes of action which might involve either local-mixed or transitory-mixed aclions, or a combination of the two. ${ }^{22}$ In any event, it is beheved that the foregoing simple and typically recurrent forms of mixed actions provide an adequate basis for an analysis of historical development and for postulating theoretical principles adequate to accommodate all possible variations in fact siluation.

It will be seen from the foregoing discussion that an underlying assumption is the joinder of at least two separate causes of action. Where there are multiple theories or different forms of relief sought but only one cause of action pleaded, the problem of venue is not one of choice or reconciliation between mutually inconsistent statutory venue provisions. It is simply a matter of appropriate classification of the action to determine the governing venue provision. Such classification is normally handled doctrinally in

\footnotetext{
19 Hale v. Bohannon, 38 Cal. 2d 458, 241 P.2d 4 (1952).

201 Witkin, Carifornia Procedure 745-46 (1954).

21 Cal. Code Crv. Proc. $\$ 393$.

22 E.g., Beutke v. American Securities Co., 132 Cal. App. 2d 354, 282 P.2d 201 (1955); Pacific Bal Industries v. Northern Timber, Inc., 118 Cal. App. 2d 815, 259 P.2d 465 (1953).
} 
terms of the "main relief rule" or the "incidental test." Cases of this type are not directly pertinent to our present topic. However, the theoretical distinctions between separate causes of action and different forms of relief obtainable within the framework of a single cause of action are by no means crystal clear. Hence one occasionally finds a court deciding a venue problem on alternative grounds ${ }^{24}$ - first on the assumption that only one cause of action has been pleaded but different forms of relief sought and second on the assumption that more than one cause of action has been pleaded. Where the same result can be justified under either assumption, this "either-or" technique may adequately serve to excuse the necessity for making a specific decision as to the precise nature of the plaintiff's pleading. Paradoxically, however, a decision thus predicated upon alternative grounds is regarded as authoritative, and citable as a holding, upon either ground. ${ }^{25}$ Accordingly, no attempt will here be made to analyze cases founded upon such alternating grounds to determine the merits of the underlying alternative assumptions. Such decisions will be treated as equally authoritative in both aspects.

\section{HISTORICAL BEGINNINGS}

The theoretical foundations of the divergent approaches to solution of mixed action venue problems were laid down in three early cases decided between 1884 and 1891. The first of these, LeBreton v. Superior Court, ${ }^{26}$ strictly speaking, did not involve a pure venue problem but rather the question whether the superior court of San Francisco lacked jurisdictional venue $^{27}$ and hence was amenable to a writ of prohibition. An action had been brought against the administrator of the estate of the trustee of a trust deed to enforce its provisions for the benefit of certain beneficiaries. The corpus consisted of real property and the rents, issues, and profits therefrom. Defendant, in petitioning for prohibition, urged that since the land in question was located elsewhere than in San Francisco, the court had no jurisdiction in view of section 5 of article VI of the constitution. ${ }^{28}$ Respondent urged, in part, that since the object of the proceeding was to reach personal property as well as realty, the action was not wholly within the con-

231 Witrin, California Procedure 703, 749 (1954).

24 E.g., Brown Materials Co. v. Angus, 20 Cal. App. 2d 32, 66 P.2d 470 (1937); Brown v. Happy Valley Fruit Growers, 206 Cal. 515, 274 Pac. 977 (1929).

25 Estate of McSweeney, 123 Cal. App. 2d 787, 268 P.2d 107 (1954); Gaskill v. Richmaid Ice Cream Co., 111 Cal. App. 2d 745, 245 P.2d 53 (1952); Bank of Italy v. Bentley, 217 Cal. 644, 20 P.2d 940 (1933); King v. Pauly, 159 Cal. 549, 115 Pac. 210 (1911).

2866 Cal. 27, 4 Pac. 777 (1884).

27 The distinction between ordinary waivable venue and non-waivable jurisdictional venue is observed in Brock v. Superior Court, 29 Cal. 2d 629, 177 P.2d 273 (1947). See 1 WiTrIs, Calmornat Procedure 707 (1954).

28 See note 5 supra. 
stitutional provision and that "in such case, there is concurrent jurisdiction created by law in the court of the county in which the defendant resides."20

The supreme court held that the trial court had jurisdiction. But the explanation why this was so is far from clear. The opinion does not attempt to set forth reasons in the court's own words but merely quotes from a pair of analogous out-of-state cases. The Georgia case of Black $v$. Black $k^{30}$ supported the view urged by respondent that jurisdiction (or venue) of an action which is in part local and in part transitory may be laid in either county. ${ }^{31}$ The Alabama case of Ashhurst v. Gibson, ${ }^{32}$ however, appeared to refute the concurrent venue theory in favor of exclusive venue in the county of defendant's residence by stating that the venue provision concerning suits over realty is available only where the realty is the "exclusive subjectmatter" of the action. ${ }^{33}$

The obvious theoretical differences between the two cited cases was not regarded as a deterrent to their concurrent citation in LeBreton. Under the facts before the California court, of course, the same result obtained under both views. Yet it would appear that with equal propriety the plaintiff could have sued in the county where the land lay under the concurrent jurisdiction theory advanced in the Georgia case. Had he done so, however, a dismissal would have been in order pursuant to the Alabama exclusive subjectmatter theory under which only the county of defendant's residence would seem to be proper venue.

Since LeBreton was a prohibition rather than venue proceeding it left unresolved the possibility that even though plaintiff could initially invoke the jurisdiction of either of two courts having concurrent jurisdiction the defendant might be able to elect the other as venue for trial by making a motion for change of venue under the count as to which (considered separately) venue was presently improper. This possibility became an actuality,

\footnotetext{
${ }^{29}$ LeBreton v. Superior Court, 66 Cal. 27, 29, 4 Pac. 777, 779 (1884).

$3027 \mathrm{Ga} .40$ (1859).

31 In Black the issue was whether a previous action was res judicata or nugatory because, since it involved title to realty as well as a transitory action, it was not brought in the county where the land lay but in the county of defendant's residence. The court said: "There was ... at least as much reason that the bill should be brought in the county in which it was brought, as there was that it should be brought in the other county .... This being so, a Court of equity of either county would have jurisdiction of the case." Id. at 45-46. (Emphasis added.)

3257 Ala. 584 (1877).

33 The court noted that under the pertinent statutes in a real property suit "the locality of the real estate, and of residence, alike confer jurisdiction, and the complainant may, at his pleasure, elect the one or the other jurisdiction." However, this right of election was clearly "limited to suits, the subject-matter of which is real estate." The difficulty with the case at hand, then, was that it sought relief with respect to both real and personal property, and hence "the suit has not for its subject-matter land, but personal property and land ...."Id. at 587.
} 
or at least apparently so, in a miscellaneous-mixed action entitled $A h$ Fong v. Sternes. ${ }^{34}$

Ah Fong sued in the superior court of Nevada County to recover damages for unlawful imprisonment imposed upon him by defendant's alleged refusal to obey a writ of habeas corpus. Viewed as an action to recover the statutory penalty provided in such cases, ${ }^{35}$ venue was proper in Nevada County where the cause of action arose $;^{\mathbf{3 6}}$ but regarded as an ordinary action for false imprisonment, venue was proper only in Sutter County where defendant resided. ${ }^{37}$ Pointing out that the complaint apparently "was framed with a double aspect," and hence could "be regarded as stating two separate causes of action, upon one of which the defendant would be entitled to a change of venue but not upon the other, ${ }^{238}$ the court held that defendant's motion to change venue to the county of his residence should have been granted. A plaintiff, said the court, ${ }^{39}$

cannot deprive the defendant of his right to a change of venue by the addition of something to the complaint. If this were not the rule, it would be very easy for a plaintiff to defeat the defendant's right in the matter. All that plaintiff would have to do would be to add another cause of action to his complaint. It need not be a genuine cause of action.

Ah Fong, like the LeBreton case, bears within it the seeds of inconsistency. The court, by the language just quoted, seems to accept the "concurrent" theory enunciated in LeBreton and applies it to a pure venue problem. Taken as authoritative generalization, moreover, it would tend to support the view that if the facts had been exactly reversed-that is, if Ah Fong had laid venue in Sutter County where defendant resided-Sternes could have successfully moved to change venue to Nevada County which had concurrent venue. The logic is a perfect parallel: Plaintiff cannot deprive defendant of his statutory right to venue of the penalty action in Nevada County by adding to the complaint another count for false imprisonment triable in Sutter. In short, the $A h F$ ong opimion suggests that a mixed action defendant may elect between two inconsistent but equally applicable venue provisions upon which he wishes to rely. This theory for resolving mixed action venue problems is still reflected in modern decisions. For the sake

3479 Cal. 30, 21 Pac. 381 (1889). The official report spells defendant's name variously as "Sternes" and "Stearnes."

35 CAL. PEN. CoDE $\$ 1505$, as enacted in 1872, provides in part: "If . . the officer or person to whom such writ [of habeas corpus] may be directed, refuses obedience to the command thereof, he shall forfeit and pay to the person aggrieved a sum not exceeding five thousand dollars, to be recovered by action in any court of competent jurisdiction."

36 Cad. Code Crv. Proc. $\$ 393$ (1872).

37 CaI. Code Crv. Proc. $\$ 395$ (1872).

38 Ah Fong v. Sternes, 79 Cal. 30, 33, 21 Pac. 381, 382 (1889).

39 Id. at 33,21 Pac. at 382 . 
of brevity and accuracy it may be referred to as the "defendant's election theory."

The foregoing explanation of Ah Fong might be fully acceptable if it were not for the fact that the court, in a slightly different context, also stated: "Now, we do not think that the plaintiff, by so framing his complaint [in an ambiguous double aspect], can deprive the defendant of his right to have the case tried in the county of his residence." ${ }^{40}$ The italicized words may, of course, be brushed aside as of little significance in view of the fact that defendant's motion was in fact to transfer the action to the county of his residence. But the language used suggests the possibility that defendant in a mixed action may not have a free election between alternative concurrent venue choices. He may instead have only the right to insist on residence-venue where that has been improperly denied under one count or the other. If this be so and had Ah Fong commenced his action in Sutter County where Sternes resided, a motion by the latter to change venue to Nevada County would be denied since the joinder of counts had not deprived defendant of his right of residence venue. Such a result is directly contrary to that indicated by the "defendant's election" theory. For convenience this rationale may be referred to as the "defendant's right theory."

The first opinion of the supreme court attempting a full theoretical discussion of the mixed action venue problem was handed down in 1891-the oft-cited case of Smith v. Smith. ${ }^{41}$ Unfortunately, instead of resolving the uncertainties of theory suggested by the previous cases, the Smith opinion only perpetuated them.

Smith v. Smith was commenced in Tuolumne County against a defendant residing in Merced County. Plaintiff was seeking to have a conveyance of real and personal property declared to be a mortgage; to obtain a reconveyance of the property embraced thereby; and to secure an accounting and money judgment. Insofar as the action involved a determination of whether a deed to real property situated in Tuolumne County was in fact a mortgage, venue was proper in that county under section 392 of the Code of Civil Procedure. ${ }^{42}$ The cause of action for an accounting, on the other hand, if sued on alone, was triable only in the county of defendant's residence under section $395 .^{43}$ Defendant's motion to change venue to the county of his residence was denied by the trial court. This order was reversed on appeal. Without even the courtesy of citation the court bypassed the recent $A h$ Fong opinion and reverted to the exclusive subject-matter theory enunciated in LeBreton. Declaring the residence venue rule of sec-

\footnotetext{
$4079 \mathrm{Cal}$. at 33, 21 Pac. at 381-82. (Emphasis added.)

4188 Cal. 572, 26 Pac. 356 (1891).

42 See text at note 5 supra.

43 See note 18 supra.
} 
tion 395 to be the general rule to which all other venue provisions are exceptions, the court said: ${ }^{44}$

When ... the subject-matter of the action is local, and the judgment which is sought is to operate directly upon that subject-matter, it is provided that the action shall be tried in the county where the subject-matter of the action is situated. This being an exception to the general rule, the conditions under which the exception is claimed must be clearly and distinctly shown. . . It is only when real estate alone is the subject-matter of the action that the provisions of section 392 can be invoked against a defendant who resides in a county different from that in which the land is situated. If, in his complaint, the plaintiff join with such a cause of action another which is not embraced in its provisions, or if he also seeks a remedy against the defendant upon matters which are not embraced within the provisions of this section, his action becomes one of those 'other cases' provided for in section 395, which the defendant is entitled to have tried in the county of his residence.

Unless the cause of action set forth in the complaint falls wholly within the provisions of section 392, or of one of the two next succeeding sections, the provisions of section 395 prevail.

The essence of the court's view seems to lie in the notion that all statutory venue other than defendant's residence is exceptional and statutes so providing must be applied strictly. Thus unless all counts of the complaint fall exclusively within the same statutory exception, the action is triable only in the county of a defendant's residence since the only statutory provision within which such an action as a whole then falls is the "all other cases" clause of section 395 . For convenience this theory may be referred to as the "exclusive exception theory."

The difficulty with the Smith opinion is that the court did not confine itself to the exclusive exception theory but also seems to have accepted the defendant's right concept: ${ }^{45}$

The general spirit and policy of the statute is to give to the defendant the right of having all personal actions against hin tried in the county of his residence. ... The plaintiff cannot, by uniting in his complaint matters which form the subject of a personal action with matters which form the subject of a local action, compel the defendant to have both those matters tried in a county other than that in which he resides. ... An action for an accounting is a proceeding in equity, and is essentially a personal action. The defendant has the right, under Section 395 of the Code of Civil Procedure, to have such action tried in the county of his residence. The plaintiff cannot deprive him of his right by uniting in his complaint with such action a demand for an accounting for certain rents, issues, and profits alleged to

44 Smith v. Smith, 88 Cal. 572, 576-78, 26 Pac. 356, 358 (1891). (Emphasis added.)

45 Id. at 575-77, 26 Pac. at 357-58. (Emphasis added.) 
have been received by the defendant from certain real estate situated in another county, and that he be adjudged to reconvey said real estate.

Although Ah Fong $v$. Sternes is not cited in the Smith opinion, the quoted language bears a very close resemblance to that used in $A h$ Fong. The exclusive exception and defendant's right theories, of course, both supported the conclusion reached in Smith $v$. Smith. Yet under different circumstances inconsistent conclusions are distinctly possible depending on the theory relied upon. For example, venue of an action in which a count for injury to real property is joined with one for injury to personal property would be proper only in the county of a defendant's residence under the exclusive exception theory. ${ }^{46}$ But the defendant's right rationale would sustain plaintiff's choice of venue not only there but also in the county where the realty is located if the injury to personal property took place in the latter county. ${ }^{47}$ On the other hand, under the defendant's election theory the defendant, by timely motion, could insist upon venue at the situs of the realty, if the action were commenced either at defendant's residence or where the injury to personalty occurred, and could insist upon a change of venue to either of the latter two places if the action were commenced at the former..$^{48}$

It seems incredible, but it is true, that during the more than half century which has elapsed since $S$ mith $v$. Smith was decided there has been no judicial effort at a definitive reconciliation of these three theoretical approaches with their potentially inconsistent results. Although all three theories are reflected in the cases, often in the same opinion, ${ }^{40}$ the judicial language seldom discloses even the slightest awareness of the potential inconsistency. Uncertainty of adjective law is the least defensible of legal

46 If sued on alone, the first count would be governed by section 392 and the second by section 395 . Since the entire action is not exclusively within one of the exceptions, it would be classified as one of the "all other cases" referred to in section 395.

47 Venue of the real property count would be good in the situs county under section 392 and would be equally good there for the personal property count under the property injury clause of section 395, which authorizes venue of such an action either in the residence county or the county in which the injury occurred. Hence, it could not be said that by joining either count plaintiff has deprived defendant of his right to residence venue under the other.

48 The potential inconsistencies observed in this paragraph were not even theoretically possible prior to the 1911 amendment to section 395 which enlarged venue of property daunage cases to include the county where the injury occurred. Cal. Stat. 1911, c. $421, \S 1$. The difficulty noted in the text, it may be suggested, is thus not so much due to inability on the part of the writers of the early opinions to foresee the inconsistencies inherent in the different theories invoked as to the failure of more recent courts to appreciate the impact of statutory hberalization of venue upon the applicability of the older doctrines.

49 Pacific Bal Industries v. Northern Timber, Inc., 118 Cal. App. 2d 815, 259 P.2d 465 (1953) ; Claycomb v. Caronna, 113 Cal. App. 2d 561, 248 P.2d 779 (1952) ; Goossen v. Chifton, 75 Cal. App. 2d 44, 170 P.2d 104 (1946); Hays v. Cowles, 60 Cal. App. 2d 514, 141 P.2d 26 (1943); Cliew v. Storrie, 108 Cal. App. 313, 291 Pac. 610 (1930); Brown v. Happy Valley Fruit Growers, 206 Cal. 515, 274 Pac. 977 (1929); Winterburn v. Sheriff, 61 Cal. App. 531, 215 Pac. 406 (1923) ; Donohoe v. Rogers, 168 Cal. 700, 144 Pac. 958 (1914). 
uncertainties. Yet the continued appearance of all three mixed action venue theories, supported by little except bare citation of prior cases equally barren of careful analysis, can scarcely be regarded as productive of predictability. To an examination and appraisal of these later cases we now turn.

\section{LOCAL-MTXED ACTIONS}

In the disposition of change-of-venue motions addressed to complaints joining local and transitory causes of action, the exclusive exception theory lias been invoked in a majority of the cases. ${ }^{50}$ Discussion of the underlying rationale, however, is seldom encountered. Instead, the courts content themselves with sterile formulistic statements of the result. "When local and transitory actions are jomed in the same complaint, the action is regarded as transitory ...." " $[I] \mathrm{f}$ real and personal actions are joined in the same complaint the case falls within section 395 of the Code of Civil Procedure, and must be tried in the county of the defendant's residence."52

Application of the exclusive exception theory has been logically consistent. Since the theory presupposes a joinder of two counts governed by different venue provisions, it has no application to joinder of two or more counts all of which are local ${ }^{53}$ Such cases are not mixed actions. In a long line of decisions involving true local-mixed actions the exclusive exception theory has provided doctrinal support for sustaining a change of venue from the realty-situs county to the defendant's-residence county ${ }^{54}$ and for denying a change from the latter to the former..$^{55}$

50 In addition to the cases cited below, notes 51-54 infra, see Hardy v. White, 130 Cal. App. 2d 550, 279 P.2d 126 (1955); Martinez v. Martinez, 99 Cal. App. 2d 425, 221 P.2d 986 (1950); Lyons v. Brunswick-Balke-Collender Co., 20 Cal. 2d 579, 127 P.2d 924 (1942); Sheeley v. Jones, 192 Cal. 256, 219 Pac. 744 (1923); Nason v. Feldhusen, 34 Cal. App. 789, 168 Pac. 1162 (1917); Donohoe v. Rogers, 168 Cal. 700, 144 Pac. 958 (1914); Booker v. Aitken, 140 Cal. 471, 74 Pac. Il (1903).

51 Eckstrand v. Wilshusen, 217 Cal. 380, 382, 18 P.2d 931, 932 (1933). To the same effect, see Beutke v. American Securities Co., 132 Cal. App. 2d 354, 282 P.2d 201 (1955); Henderson v. Henderson, 85 Cal. App. 2d 476, 193 P.2d 135 (1948); Vaughan v. Roberts, 45 Cal. App. 2d. 246, 113 P.2d 884 (1941); Weygandt v. Larson, 130 Cal. App. 304, 19 P.2d 852 (1933); Taaffe v. Bloch, 127 Cal. App. 678, 16 P.2d 303 (1932).

62 Warner v. Warner, 100 Cal. 11, 16, 34 Pac. 523, 524 (1893).

63 Strosnider v. Pomin, 32 Cal. App. 2d 103, 89 P.2d 179 (1939); cf. Neet v. Holmes, 19 Cal. 2d 605, 122 P.2d 557 (1942).

54 Claycomb v. Caronna, 113 Cal. App. 2d 561, 248 P.2d 779 (1952); Bybee v. Fairchild, 75 Cal. App. 2d 35, 170 P.2d 54 (1946); Hays v. Cowles, 60 Cal. App. 2d 514, 141 P.2d 26 (1943); Blackman v. Sherman, 41 Cal. App. 2d 20, 105 P.2d 1000 (1940); Turlock Theatre Co. v. Laws, 12 Cal. 2d 573, 86 P.2d 345 (1939), 27 CaLIF. L. Rev. 468; Stesel v. Santa Ana River Water Co., 35 Cal. App. 2d 117, 94 P.2d 1052 (1939); Howe v. Tucker, 219 Cal. 193, 25 P.2d 832 (1933); Taaffe v. Bloch, 127 Cal. App. 678, 16 P.2d 303 (1932); Perkins v. Winder, 123 Cal. App. 467, 11 P.2d 394 (1932); Chew v. Storrie, 108 Cal. App. 313, 261 Pac. 610 (1930); Brown v. Happy Valley Fruit Growers, 206 Cal. 515, 274 Pac. 977 (1929); cf. Beutke v. American Securities Co., 132 Cal. App. 2d 354, 282 P.2d 201 (1955).

o5 Neet v. Holmes, 19 Cal. 2d 605, 122 P.2d 557 (1942); $c f$. Vaughan v. Roberts, 45 Cal. App. 2d 246, 113 P.2d 884 (1941). 
Similar conclusions have been reached and justified under the defendant's right theory. ${ }^{56}$ The usual formulation uses the language of estoppel: " $[P]$ laintiffs cannot, by uniting in their complaint matters that are the subject of a personal action with those that are the subject of a local action, compel defendant to have both matters tried in a county other than that in which he resides..257 Occasionally an analogous verbalization in terms of waiver, ${ }^{58}$ but essentially predicated on the same basic theory, is encountered: "The uniting of a personal action with one in rem waives the right conferred by section $392 \ldots$ to try the case in the county where the property is located," ${ }^{59}$ Although the courts uniformly verbalize the defendant's right theory in terms which inupute intent or purpose to the plaintiff, in the application of that theory such matters become irrelevant for it is the effect of the joinder which controls irrespective of the plaintiff's motivations.

The defendant's election theory has not been used in the actual solution of local-mixed venue problems. It has, however, been expressed in dictum either inadvertently or by design. To the former explanation may be assigued substantially identical language in Goossen v. Clifton ${ }^{00}$ and Bybee v. Fairchild, ${ }^{61}$ both of which were decided on the same day over the signature of the same author. It is "well settled," said Mr. Presiding Justice Peters, "that when a transitory action in personam is joined with a local action, the defendant is entitled to a change of venue, although had the local action been sued upon alone, no such right to a change would exist." ${ }^{\prime 2}$ Although the quoted langnage was very probably not intended to express

56 Change of venue from realty-situs county to defendant's residence county affirmed: Chew v. Storrie, 108 Cal. App. 313, 291 Pac. 610 (1930) ; Terry v. Rivergarden Farms Co., 29 Cal. App. 59, 154 Pac. 476 (1915); see also Donohoe v. Rogers, 168 Cal. 700, 144 Pac. 958 (1914). Order denying such change of venue reversed: Keithly v. Lacey, 77 Cal. App. 2d 339, 175 P.2d 235 (1946); Hays v. Cowles, 60 Cal. App. 2d 514, 141 P.2d 26 (1943); Brown v. Happy Valley Fruit Growers, 206 Cal. 515, 274 Pac. 977 (1929); White v. Adler, 5 Cal. Unrep. 215, 42 Pac. 1070 (1895) ; see also Rogers v. Rihn, 132 Cal. App. 2d 185, 281 P.2d 546 (1955) (affirming an order changing venue from "neutral" county to county in which land is situated and defendants reside).

57 Keithly v. Lacey, 77 Cal. App. 2d 339, 341, 175 P.2d 235, 236 (1946). To same effect, Hays v. Cowles, 60 Cal. App. 2d 514, 141 P.2d 26 (1943) ; Brown v. Happy Valley Fruit Growers, 206 Cal. 515, 274 Pac. 977 (1929); Terry v. Rivergarden Farms Co., 29 Cal. App. 59, 154 Pac. 476 (1915).

58 "Waiver" language is more frequently employed as the defendant's right rationale in corporation-mixed cases. See note 101 infra.

59 Chew v. Storrie, 108 Cal. App. 313, 315, 291 Pac. 610, 611 (1930).

6075 Cal. App. 2d 44, 170 P.2d 104 (1946).

6175 Cal. App. 2d 35, 170 P.2d 54 (1946).

62 Id. at 37, 170 P.2d at 56; see also Goossen v. Clifton, 75 Cal. App. 2d 44, 49, 170 P.2d 104,108 (1946). 
judicial acceptance of the defendant's election theory, ${ }^{63}$ taken out of context it provides logical support for application of that theory. To state without reservation or limitation that in a local-mixed action "defendant is entitled to a change of venue" is to suggest that he is entitled, whenever venue as laid is improper as to either count, to change venue either to a county where it would be triable with respect to the local count or to a county where it would be triable with respect to the transitory count. Indeed, in Brown Materials Co. v. Angus ${ }^{64}$ the California District Court of Appeal for the Third Appellate District had previously attempted to formulate a rule precisely to that effect.

In the Brozen case, plaintiffs' brief posed the defendant's election issue squarely: ${ }^{65}$

Where both a local and a transitory action are joined and suit is commenced in a county other than the residence of defendant or the location of the real property involved, has the defendant an optional right to have the venue of the action changed either to the county of the situs of the real property or to the county of defendant's residence?

The issue, as thus framed, was occasioned by the trial court's order granting defendants" motion to change venue from the "neutral" county in which it had been commenced to the county in which the real property was located - that is, not the county in which one of the defendants resided. The appellate court at first side-stepped, holding that the action was not a true local-mixed action, as postulated by plaintiffs, but was essentially an action relating to real property in which incidental transitory relief was sought. As such, venue was governed exclusively by section $392 .{ }^{68}$ In the latter portions of the opinion, however, the court examined a number of the mixed action $\operatorname{cases}^{67}$ in some detail and arrived at the following synthesis: ${ }^{88}$

The principles involved in the cases cited herein are as follows: 1 st. The defendant is entitled to have a local action tried in the county where the real property is located (sec. 392, Code Civ. Proc.); 2 d. The defendant is entitled to have a personal action tried in the county of his residence (sec. 395, supra); 3d. The plaintiff may not deprive a defendant of either of these rights by joining a second cause of action in his complaint. If both

63 In both of the cited cases the quoted words are accompanied by repeated formulations of the exclusive exception theory and to a lesser extent the defendant's right theory. Since both decisions upheld defendant's right to a change of venue to the county of his residence, any imphication that in other circumstances defendant might be entitled to a change of venue to some non-residence county may be regarded as fortuitous.

64 20 Cal. App. 2d 32, 66 P.2d 470 (1937).

65 Id. at 32,66 P.2d at 470 .

${ }^{66}$ See 1 Within, California Procedure 703 (1954).

Bi E.g., Smith v. Smith, 88 Cal. 572, 26 Pac. 356 (1891); Howe v. Tucker, 219 Cal. 193, 25 P.2d 832 (1933).

6820 Cal. App. 2 d at $37-38,66$ P.2d at 473 . (Emphasis added.) 
types of action are so joined, the defendants may insist on trial in either court (sec. 398, supra).

As direct support for the words we have emphasized, the court quoted at length from Ah Fong v. Sternes" and declared flatly that the "right of the defendants to designate a proper county, or the proper county for the trial of the action, is specially given by section 398, supra."70 The latter statement, of course, really begs the question whether the realty-situs county is proper: it assumes that either county is proper and hence could be properly designated by defendant as the transferee county.

It will not do to say that it makes no difference which theory is employed to solve local-mixed action venue problems. A theory once enunciated tends to become a generative principle. Even though the holdings in the cases have not been inconsistent ${ }^{71}$, for the most part, the potentiality of inconsistency in other future cases is sufficient ground for concern. Such potentiality becomes apparent from a brief consideration of the inherent characteristics of each theory. With reference to local-mixed actions, these characteristics are easily discernible. The exclusive exception theory leads inevitably to the defendant's residence as the only possible venue county since the very hypothesis of joinder of local and transitory counts by definition removes the case from the exclusive ambit of section 392 . The defendant's right theory normally leads to the same conclusion but offers the possibility of alternative venue in the realty-situs county whenever that county is also a proper county for trial of the joined transitory count, for in such a case the joinder has not deprived defendant of a right to residence-venue assertable under the transitory count. ${ }^{72}$ The defendant's election theory seems to go even further and apparently would permit the defendant to insist upon a change of venue either to a county designated as proper for the realty count or to a county designated as proper for the transitory count, e.g., defendant's residence, place of personal injury, place where

6979 Cal. 30, 21 Pac. 381 (1889).

7020 Cal. App. 2 d at 38, 66 P.2d at 473. CAa. CODE CIv. Proc. $\$ 398$ provides in part that on a motion for change of venue on "wrong court" grounds, the action "inust be transferred to ... a proper county, designated by the defendant ... in the notice of motion for change of venue or in open court ...."

71 But compare Brown Materials Co. v. Angus, 20 Cal. App. 2d 32, 66 P.2d 470 (1937) with Neet v. Holmes, 19 Cal. 2d 605, 122 P.2d 557 (1942). See text at note 110 infra.

72 It is settled that where alternative venue choices are authorized by statute, defendant has no right to insist upon one or the other of the several equally "proper" counties, but plaintiff may lay venue in any one of them. Ward Mfg. Co. v. Miley, 131 Cal. App. 2d 603, 281 P.2d 343 (1955); Shulzmer Watch Co. v. Cortal, 130 Cal. App. 2d Supp. 901, 280 P.2d 228 (1955); Pacific Bal Industries v. Northern Timber, Inc., 118 Cal. App. 2d 815, 259 P.2d 465 (1953); Monogram Co. v. Kingsley, 38 Cal. 2d 28, 237 P.2d 265 (1951), 25 So. CAITr. L. REv. 491 (1952); Case v. Kirkwood, 119 Cal. App. 207, 6 P.2d 110 (1931); Aisbett v. Paradise Mountain Mining \& Milling Co., 21 Cal. App. 267, 131 Pac. 330 (1913). 
contract entered into or expressly performable, whenever the action was commenced in a county ${ }^{\circ}$ which was improper as to both joined causes of action. ${ }^{73}$ However, if the county in which the action was commenced was proper as to one of the joined counts, defendant's election would apparently be limited to insisting on a change of venue to a county which would be proper as to the other count, that is, he could not insist on transfer to a county which was alternatively proper venue with respect to the former count. $^{74}$

Results postulated on the preceding analysis, of course, are not automatic. Defendant's objection to improper venue is waived by failure to make a timely motion ${ }^{75}$ supported by technically accurate moving papers. ${ }^{76}$ Even where the motion is procedurally correct, it will be denied if defendant designates an improper county in his notice of motion as the one to which he requests that the action be transferred. ${ }^{77}$ Procedural requirements, however, are but means to the end of orderly selection of place of trial. The practical consequences flowing from application of the different theoretical approaches discussed above are far from orderly even in the limited context of local-mixed actions. The potentially conflicting results may best be indicated in graphic form. (See Appendix A.)

\section{TRANSITORY-MIXED ACTIONS}

The exclusive-exception theory is encountered in a few transitory-mixed actions with logically consistent results. When, in such an action, venue of the several transitory counts is governed by the same statutory provision and the plaintiff commences it in a non-residence county which is proper as to every count, defendant's motion to transfer to his residence-county

\footnotetext{
${ }^{73}$ See Brown Materials Co. v. Angus, 20 Cal. App. 2d 32, 66 P.2d 470 (1937).

${ }_{74}$ Cases cited note 72 supra.

${ }_{75}$ CaL. Code Civ. Proc. $\$ 396 \mathrm{~b}$; Lyons v. Brunswick-Balke-Collender Co, 20 Cal. 2d 579, 127 P.2d 924 (1942).

76 Anderson v. No-Doz, 134 Cal. App. 2d 11, 284 P.2d 883 (1955) (insufficient affidavit of merits); Weber v. Purdy, 84 Cal. App. 2d 482, 191 P.2d 66 (1948) (failure to file memorandum of points and authorities).

77 Beutke v. American Securities Co., 132 Cal. App. 2d 354, 282 P.2d 201 (1955) (reversing order granting defendant's motion to change venue from improper county where commenced to another county equally improper) "It is clear that ... respondents would have been entitled to a transfer of the action to the county of their residence [San Francisco] if their motion had been to transfer it to such county. However, the record shows that respondent's motion was to transfer the action to the county of Alameda ..." Id. at 360, 282 P.2d at 205. Sausen v. Anderton, 129 Cal. App. 2d 324, 276 P.2d 814 (1954) (affirming order denying motion to change venue to improper county) "The defendants had an absolute right upon request to have the trial moved to one or the other of the counties of their residence. This does not mean that they could agree upon a county in which neither resided and have the cause moved to such county." Id. at 326,276 P.2d at 815 .
} 
is denied. ${ }^{78}$ Of course this result is a correct application of the exclusive exception theory since "under the allegations in each count, the complaint has been framed to show that plaintiff comes within an exception from the general provision that defendant is entitled to a trial in the county of his residence ..." ${ }^{79}$ On the other hand, where a non-residence county is improper as to one of the counts, even though good as to the rest, the entire action is held to be transferable to the county of defendant's residence because the entire action is not within the statutory authorization for venue elsewhere. ${ }^{80}$ Similarly, if each of the joined counts is governed by a different venue provision, the action cannot be classified as within either statutory exception and defendant's residence county is the only proper venue. ${ }^{81}$

The defendant's right theory, which first appeared in a transitory-mixed action, ${ }^{82}$ only infrequently has appeared as a decisional factor in subsequent cases of this type. ${ }^{83}$ Yet the basic rationale of the old $A h$ Fong opinion is clearly reflected in these few instances. In Goossen v. Clifton, ${ }^{84}$ for example, an order denying a change of venue to defendant's residence county was held to be erroneous and thus reversible where venue as laid was iniproper as to one of two joined contract counts: ${ }^{85}$

The important right to protect is that of the defendant to have the cause tried in the county of his residence. . . . If, by joining several causes of

78 Ward Mfg. Co. v. Miley, 131 Cal. App. 2d 603, 281 P.2d 343 (1955) (joinder of two contract counts; venue held proper in county where both contracts entered into); Bloom v. Carpenter, 74 Cal. App. 2d 790, 169 P.2d 388 (1946) (semble) ; Pacific Bal Industries v. Northern Timber Inc., 118 Cal. App. 2d 815, 259 P.2d 465 (1953) (five contract counts each of which supported venue in county other than principal place of business of corporate defendant).

79 Bloom v. Carpenter, 74 Cal. App. 2d 790, 793, 169 P.2d 388, 390 (1946).

80 Pacific Bal Industries v. Northern Timber, Inc., 118 Cal. App. 2d 815, 259 P.2d 465 (1953) (venue improper as to personal defendants under one out of five joined contract counts); Crofts \& Anderson v. Johnson, 101 Cal. App. 2d 418, 225 P.2d 594 (1950) (venue held improper in absence of showing of facts justifying venue where laid under one of two joined contract counts); Goossen v. Clifton, 75 Cal. App. 2d 44, 170 P.2d 104 (1946) (venue held improper for entire action where shown to be improper for one of two joined contract counts).

81 Sexton v. Simondet, 97 Cal. App. 2d 894, 218 P.2d 1021 (1950) (joinder of contract and tort counts).

82 Ah Fong v. Sternes, 79 Cal. 30, 21 Pac. 381 (1889).

83 This is probably attributable to the fact that except in actions against corporations the residence county was for many years the only proper venue of a transitory action. Alternative venue is of relatively recent vintage. In cases of personal injury, personal property damage, and wrongful death the county where the injury occurred was not designated as proper venue until 1911. Cal. Stat. 1911, c. $421, \S 1$. Authorization for alternative venue in superior court contract actions was not added until 1939. Cal. Stat. 1939, c. 981, §1.

8475 Cal. App. 2d 44, 170 P.2d 104 (1946); see also Lucas v. Lucas Ranching Co., 18 Cal. App. 2d 453, 64 P.2d 160 (1937); Jester v. Kohler \& Chase, 123 Cal. App. 53, 10 P.2d 794 (1932).

8575 Cal. App. 2d at 49-50, 170 P.2d at 108. The same opinion, it should be noted, uses extensively the language of the exclusive exception theory. 
action, the defendant could be deprived of his right, the right would be lost in many cases. It is for that reason that the courts hold that the test is whether on any one of the causes of action the defendant is entitled to a change to the county of his residence. If there is one such cause, then defendant is entitled to the change no matter how many other causes may be set forth in which he is not entitled to the change.

On the other hand, if non-residence venue as laid is proper as to each of several joined counts, defendant cannot claim that any right to residencevenue which would otherwise have been assertible has been denied him by reason of the joinder. Accordingly, in such event a motion to change venue to the residence county is properly denied. ${ }^{86}$

No transitory-mixed cases have been discovered in which the defendant's election theory has been explicitly invoked as the deciding principle. There are, however, a number of judicial statements which taken out of context appear to be in agreement with the theory and in context are not inconsistent therewith. The unqualified language in these statements suggests that the defendant's election theory may not be regarded by the courts as completely inconsequential in solving transitory-mixed venue problems. ${ }^{87}$

It is apparent that in transitory-mixed actions the three theories in question logically lead to results which under some circumstances will be wholly incompatible. The exclusive exception theory limits plaintiff's choice of proper venue to only one controlling factor-defendant's residence. The defendant's right theory enlarges the area of plaintiff's choice to include any non-residence county which is proper venue under all of the joined counts with transfer to defendant's residence the consequence of incorrect choice. The defendant's election theory provides an equally wide choice but gives defendant broad elective rights to insist upon venue where plaintiff could not do so. These differences have also been reduced to graphic form. (See Appendix B.)

86 Gilman v. Nordin, 112 Cal. App. 2d 788, 247 P.2d 394 (1952).

87 Consider this statement from Ward Mfg. Co. v. Miley, 131 Cal. App. 2d 603, 281 P.2d 343 (1955): "[A] defendant who would be entitled to a change of venue on one contractual cause of action if it were the only one, remains entitled to such change regardless of the joinder of one or more other causes in which he would not be entitled to a transfer." Id. at 605, 281 P.2d at 345. See also Pacific Bal Industries v. Northern Timber, Inc., 118 Cal. App. 2d 815, 259 P.2d 465 (1953); Erwin v. Cee-Tee Construction Co., 114 Cal. App. 2d 364, 250 P.2d 287 (1952) ; Abbott v. Peoples Nat'l Fire Ins. Co., 132 Cal. App. 357, 22 P.2d 544 (1933); Sanborn v. Pomona Pump Co., 131 Cal. App. 241, 21 P.2d 124 (1933).

While statements in these cases would appear to support a transfer of the action to any county selected by defendant which is authorized by statute as proper venue of the contractual cause of action, the breadth of language used is qualified by the fact that the motions under consideration were to change venue to the defendant's residence or, in cases of corporate defendants, principal place of business. 


\section{CORPORATION-MTXED ACTIONS}

Although the doctrinal framework of corporation-mixed actions has, in the main, been erected around the defendant's right theory, ${ }^{88}$ cases of this type are not entirely barren of "exclusive-exception" language. ${ }^{80}$ When a complaint names as defendants both a corporation, as to whom proper venue is defined by section 16 of article XII of the constitution, ${ }^{00}$ and a natural person, as to whom proper venue is defined by sections 392 through 401 of the Code of Civil Procedure, the exclusive-exception theory seems to be fully applicable. ${ }^{11}$ Such action as a whole is not exclusively within either the constitutional provision or any specific code section. It is therefore one of the "all other cases" required by section 395 to be laid in the county of a defendant's residence. Upon the basis of this line of reasoning the individual defendant may successfully move to change the venue of the entire case to the county of his residence ${ }^{92}$ even though the action has been instituted in a county "where the contract is made or is to be performed, or where the obligation or liability arises, or the breach occurs, ${ }^{\prime 103}$ that is, a county which is proper venue as to the corporate defendant. By the same token since a corporation's principal place of business is regarded as its residence for venue purposes, ${ }^{04}$ the individual defendant's motion is just as readily granted if it desiguates the county of the corporate principal place of business as the transferee county. ${ }^{95}$ This result follows logically from the fact that section 395, the only applicable venue provision under the

88 See text at note 99 infra.

89 See Deas v. Lido Lumber Co., 132 Cal. App. 2d 402, 282 P.2d 90 (1955). The court employed "exclusive exception" language as governing application of Car. CoNst. art. XII, $\S 16$, in a non-mixed action.

00 CAL. Const. art. XII, $\S 16$, provides: "A corporation or association may be sued in the county where the contract is made or is to be performed, or where the obligation or liability arises, or the breach occurs; or in the county where the principal place of business of such corporation is situated, subject to the power of the court to change the place of trial as in other cases."

01 Hale v. Bohannon, $38 \mathrm{Cal} .2 \mathrm{~d} 458,241$ P.2d 4 (1952). One important exception lias been judicially engrafted: venue of actions governed by CAx. CODE Crv. Proc. $§ 392$, when brouglit against corporate defendants, is controlled by the code section rather than by the constitutional provision in order to avoid conflict with the equal protection clause of the United States Constitution. Grocers' Fruit Growing Union v. Kern County Land Co., 150 Cal. 466, 89 Pac. 120 (1907). In addition, it sliould be noted that venue of actions against unincorporated associations appears to be governed in part by section 16 of article XII and in part by CAL. CODE Crv. Proc. § 395. Juneau Spruce Corp. v. International Longshoremen's Union, $37 \mathrm{Cal}$. 2d 760, 235 P.2d 607 (1951).

92 Griffen \& Skelly Co. v. Magnolia \& Healdsburg Fruit Cannery Co., 107 Cal. 378, 40 Pac. 495 (1895) ; Brady v. The Times-Mirror Co., 106 Cal. 56, 39 Pac. 209 (1895).

93 See note 90 supra.

94 Hale v. Bohannon, 38 Cal. 2d 458, 241 P.2d 4 (1952).

95 Walker v. Wells Fargo Bank \& Union Trust Co., 24 Cal. App. 2d 220, 74 P.2d 849 (1937). See also McSherry v. Pennsylvania Consol. Gold Mining Co., 97 Cal. 637, 32 Pac. 711 (1893). 
exclusive-exception theory, authorizes trial of "other cases" in the county in which any one of the defendants resides. ${ }^{96}$

Similarly, if a corporation-mixed action is commenced in the county in which the principal corporate office is located, the venue requirements of section 395 are satisfied and a motion to transfer to the mdividual defendant's residence is properly denied. ${ }^{97}$ In the exact converse situation the corporation's motion to transfer from the individual defendant's residence county to its principal place of business is also denied for the same reason. ${ }^{98}$

Logic, however, yields to the limitations of legal theory when a motion to change venue to its principal place of business is made by the corporate defendant in an action brought in a county otherwise proper under section 16 of article XII. In such a case the corporation is regarded as having no standing to insist upon principal-place-of-business venue ${ }^{9 \theta}$-a result in conflict with the exclusive exception rationale but perfectly consistent with the defendant's right theory. The individual defendant, on the other hand, still retairs some rights of residence venue: ${ }^{100}$ "A plaintiff cannot [under the "defendant's right" theory] by joining a corporation or corporations as defendants ... impair the right or thwart the exercise of the right of an individual defendant to remove the cause to the county of his residence." The individual defendant's right is thus protected against impairment ${ }^{101}$ by granting a transfer to the county of his residence when the action is begun

96 Monogram Co. v. Kingsley, 38 Cal. 2d 28, 237 P.2d 265 (1951), 25 So. CAr.r. L. Rev. 491 (1952).

97 Independent Iron Works v. American President Lines, Ltd., 35 Cal. 2d 858, 221 P.2d 939 (1950); Winterburn v. Sheriff, 61 Cal. App. 531, 215 Pac. 406 (1923) ; Hellman v. Logan, 148 Cal. 58, 82 Pac. 848 (1905).

98 Delno v. Market Street Ry., 63 Cal. App. 2d 489, 147 P.2d 67 (1944).

99 Young v. John Haar Pickle Co., 139 Cal. App. 2d 534, 293 P.2d 796 (1956); Pacific Bal Industries v. Northern Timber, Inc., 118 Cal. App. 2d 815, 259 P.2d 465 (1953); Strassburger v. Santa Fe Land Improvement Co., 54 Cal. App. 7, 200 Pac. 1065 (1921). See also McClung v. Watt, 190 Cal. 155, 211 Pac 17 (1922); Nelson v. East Side Grocery Co., 26 Cal. App. 344, 146 Pac. 1055 (1915).

100 Pacific Bal Industries v. Northern Timber, Inc., 118 Cal. App. 2d 815, 828, 259 P.2d 465, 473 (1953). To the same effect, Strassburger v. Santa Fe Land Improvement Co., $54 \mathrm{Cal}$. App. 7, 200 Pac. 1065 (1921); Terry v. Rivergarden Farms Co., 29 Cal. App. 59, 154 Pac. 476 (1915); Nelson v. East Side Grocery Co., 26 Cal. App. 344, 146 Pac. 1055 (1915). See also McClung v. Watt, 190 Cal. 155, 211 Pac. 17 (1922).

101 Formulation in terins of waiver is again found to be prevalent: "[B]y joining the individual defendant with the corporate defendant, plaintiffs waived the benefit of the constitutional provision at least so far as the individual defendant was concerned." Walker v. Wells Fargo Bank \& Union Trust Co., 24 Cal. App. 2d 220, 222, 74 P.2d 849, 850 (1937). See also Pacific Bal Industries v. Northern Timber, Inc., supra note 100; Strassburger v. Santa Fe Land Improvement Co., supra note 100; Nelson v. Fast Side Grocery Co., supra note 100; Griffen \& Skelly Co. v. Magnolia \& Healdsburg Fruit Cannery Co., 107 Cal. 378, 40 Pac. 495 (1895); Brady v. The Times-Mirror Co., 106 Cal. 56, 39 Pac. 209 (1895); Delno v. Market Street Ry. Co., 63 Cal. App. 2d 489, 147 P.2d 67 (1944). 
in a county improper as to him. ${ }^{102}$ But if the action is begun in the county of the corporate defendant's principal place of business, that is, its "residence," then the individual defendant's venue right is fully satisfied and a transfer to his residence is denied. ${ }^{103}$

It will be noted that the main thrust of the defendant's right theory in the present context is in the direction of subordinating the constitutional provisions goverming venue in actions against corporations to the statutory venue provided against natural persons where either or both are not satisfied. The exclusive exception theory on the other hand does not subordinate; instead it simply construes the constitutional provisions to be inapplicable.

No cases have been discovered which invoke or even refer to the defendant's election theory as a possible approach to solution of corporationmixed venue problems. Presumably, under that theory the moving party (as to whom venue would be presently improper) could designate any transferee county, not limited to a residence county, in which venue would be proper as to him. The possibility of concurrent but conflicting venue motions by the different defendants is immediately suggested ${ }^{104}$ but no doctrinal assistance in resolving the dileunma is apparent from existing judicial formulations of the theory. ${ }^{105}$ Graphic form is also used to show that a basis for inconsistent results in corporation-mixed actions is apparent. (See Appendix C.) ${ }^{106}$

102 Pacific Bal Industries v. Northern Timber, Inc., supra note 101 ; Terry v. Rivergarden Farms Co., 29 Cal. App. 59, 154 Pac. 476 (1915); Nelson v. East Side Grocery Co., supra note 101.

103 Independent Iron Works v. American President Lines, Ltd., 35 Cal. 2d 858, 221 P.2d 939 (1950); Nelson v. Marsh, 100 Cal. App. 578, 280 Pac. 695 (1929); Richmond Terminal Corp. v. Parr Terminal Co., 96 Cal. App. 152, 273 Pac. 845 (1929); Winterburn v. Sheriff, 61 Cal. App. 531, 215 Pac. 406 (1923); McClung v. Watt, 190 Cal. 155, 211 Pac. 17 (1922). Accord, Young v. John Haar Pickle Co., 139 Cal. App. 2d 534, 293 P.2d 796 (1956) (action commenced in county where contract was made).

104 E.g., motion by individual defendant to transfer to county where contract was made and concurrent motion by corporate defendant to transfer to county where contract was orally agreed to be performable.

105 The conflict suggested, note 104 suppra, might be resolved by transferring to the county in which the contract was made, which would be proper venue as to both defendants. This solution, however, would clearly limit the scope of defendant's election-a limitation for which the theory seems not to provide. Such a solution, however, would be impossible where propriety of venue in the transferee counties designated in the respective notices of motion, CaL. CODE Crv. Proc. $\$ 398$, is inutually exclusive.

108 Since venue as laid by plaintiff in the residence county of either defendant in the hypothetical situation postulated would clearly be beyond challenge by either defendant, regardless of the theory invoked, Appendix $C$ omits potential inotions in such situations. See cases cited notes $97,98,103$ supra. 


\section{APPRAISAL OF THE MTXED ACTION VENUE THEORIES}

Despite the potential disparity of holdings indicated by the foregoing survey it remains true that relatively few inconsistent decisions are found in the reports. ${ }^{107}$ Most of the reported cases have dealt with those common factual situations in which the same conclusion is supportable under each of the three theories. However, since inconsistent results may hang in the balance, an attempt at reconciliation of the three theories based upon a critical appraisal of their respective strengths and weaknesses seems justified.

The defendant's election theory has been warmly espoused in a recent publication $^{108}$ as the most desirable approach to mixed-action venue problems in that it will avoid confusion and reconcile the decided cases if uniformly followed. Unfortunately the author does not adequately advise the reader that such reconciliation would to a large extent be purely superficial and do violence to underlying theoretical concepts. Nor does he reveal the fact that the theory advocated, although supported chiefiy by obiter dictum in opinions of the district courts of appeal, has been either rejected or

107 Aisbett v. Paradise Mountain Mining \& Milling Co., 21 Cal. App. 267, 131 Pac. 330 (1913), based on the exclusive exception theory, seems contrary to Hagan v. Gilbert, 83 Cal. App. 2d 570, 189 P.2d 548 (1948), invoking the language of the defendant's election theory. The latter case, however, was expressly disapproved in Monogram Co. v. Kingsley, 38 Cal. $2 \mathrm{~d}$ 28, 237 P.2d 265 (1951), 25 So. CaIr. L. REv, 491 (1952).

Dictum in Brown Materials Co. v. Angus, 20 Cal. App. 2d 32, 66 P.2d 470 (1937), seems inconsistent with the holding of Neet v. Holmes, 19 Cal. 2d 605, 122 P.2d 557 (1942). See text at note 110 infra.

Cf. Blackman v. Sherman, 41 Cal. App. 2d 20, 105 P.2d 1000 (1940). This was an action for breach of contract, foreclosure of chattel mortgage, and to quiet title to real property in Mariposa County. Held, venue should be changed from Mariposa to defendant's residence county under "exclusive exception" rationale. However, the opinion fails to indicate whether venue would have been proper under the contract counts considered separately; but if in fact the contracts were made there or were specially agreed to be performable there, the defendant's right theory would have led to a contrary decision. See also Sexton v. Simondet, 97 Cal. App. 2d 894, 218 P.2d 1021 (1950), (semble).

The cases cited at note 99 supra illustrate the logical application of the defendant's right theory to a corporation-mixed action problem but, as indicated in the accompanying text, are inconsistent with the exclusive exception rationale. However, insofar as such inconsistency exists between Griffin and Skelly Co. v. The Magnolia and Healdsburg Fruit Cannery Co., 107 Cal. 378, 40 Pac. 495 (1895), and Young v. Joln Haar Pickle Co., 139 Cal. App. 2d 534, 293 P.2d 796 (1956), it is probably more apparent than real. Although both are corporation-mixed contract actions commenced in the county where the contract was made, Grifin \& Skelly Co. (approving change of venue to residence county) was decided in 1895, long before the 1939 amendment to CAL. Cone Crv. Proc. $\$ 395$, which authorized the contract execution county as proper venue in an action against a personal defendant; whereas Young (denying change of venue) was decided in 1956 . Venue in the contract county was thus improper as to the individual defendant at the time of the former case, but was proper at the time of the latter. The difference in result is thus attributable to legislative amendment rather than judicial change of heart.

1081 Witern, CaLtFornia Procedure 750-54 (1954). 
severely limited in recent well-considered opinions of the supreme court. The course of decision subsequent to Brown Materials Co. v. Angus ${ }^{100}$ clearly reveals the judicial nonacceptance of the "defendant's election" rationale. Neet $v$. Holmes, ${ }^{110}$ decided in 1942, presented the converse of the usual local-mixed action case in that the defendants were seeking to change venue from Los Angeles, where they resided, to Mariposa, where the real property was situated. They quite properly contended upon the basis of the Brown dictum that just as in the usual local-mixed action case the plaintiff cannot deprive defendant of residence venue by joining a local count in an otherwise transitory action, so by the same token lie could not deprive defendant of realty-situs venue througli such joinder. In short, it was argued that "when local and transitory causes of action are joined, the defendant has the choice of where the action shall be tried."111 The argument was expressly rejected and the motion to change venue was denied. For a unanimous court Mr. Justice Slienk pointed out that the Brown case had been commenced in a wholly improper, that is, "neutral," county, and that even if treated as a decision rather than dictum, Brozon "cannot be construed as a holding that a defendant would have a riglit to have an action transferred to the county where the property was situated where the action was otherwise commenced in a proper county."112 This ground of distinction, of course, wipes out the essence of the defendant's election theory and except possibly for actions commenced in "neutral" counties reduces it at inost to merely another form of the defendant's right theory.

Hagan v. Gilbert ${ }^{113}$ appears to be the only actual decision which might be said to be based upon the defendant's election theory. ${ }^{114}$ It was a transitory-mixed action upon four contract counts commenced in Los Angeles where one of the eight defendants resided. The court found that the third count stated no cause of action against the resident defendant and, on motion of other defendants who resided in San Francisco, affirmed an order granting a change of venue to the latter county. The fact that the other three counts did state a cause of action against the resident defendant was lield to be immaterial, at least in the absence of any objection by such resident defendant, ${ }^{115}$ for "when a non-resident defendant is entitled to a

10920 Cal. App. 2d 32, 66 P.2d 470 (1937), discussed in text at note 64 supra and in 1 WITKIN, supra note 108 (recognizing that the Brown opinion is only dictum, nevertheless relying upon it as the strongest case supporting the defendant's election theory).

11019 Cal. $2 \mathrm{~d} 605,122$ P.2d 557 (1942).

111 Id. at $613,122 \mathrm{P} .2 \mathrm{~d}$ at 561 .

112 Ibid.

11383 Cal. App. 2d 570, 189 P.2d 548 (1948).

114 The opinion in Hagan v. Gilbert, supra note 113 , is not entirely clear, however, and might possibly be regarded as a misapphication of the defendant's right theory.

115 The court expressly pointed out that the resident defendant had not opposed the motion and that "no question as to his right to have the action retained for trial in Los Angeles . . . was involved or decided." Id. at 578,189 P.2d at 554. 
change of venue upon one cause of action stated in a complaint, he may not be deprived of that right because plaintiff included other causes of action in the same complaint upon which such defendant is not entitled to a change of venue."116

The Hagan opinion seemed to imply that by agreement with the resident defendant the non-resident defendants could freely elect which of their respective residence counties to insist upon for trial. However, any strength Hagan thus lent to the defendant's election theory was vitiated when the supreme court expressly overruled it upon analogous facts in Monogram Co. v. Kingsley. ${ }^{117}$ The latter opinion employs the language of the exclusive exception theory in ruling that "plaintiffs have the right to select the venue within the restricted statutory limits," and hence "the consent of the resident defendant to the proposed transfer cannot deprive the plaintiffs of the right to have the action tried in the county of the consenting defendant's residence."118

Finally, in the recent case of Beutke v. American Securities Co., ${ }^{119}$ which was a lacal-mixed action commenced in the realty-situs county, the court squarely held that defendant corporation was entitled to a change of venue only to the county of its principal place of business and could not insist upon venue in some other county which was proper as to the transitory cause of action. ${ }^{120}$ In effect, the Beutke case holds that as far as corporations are concerned any venue election right in mixed actions is limited to the county of residence-precisely the effect of the defendant's right theory. ${ }^{121}$

In light of the foregoing cases the defendant's election theory must be regarded as severely limited if not wholly repudiated. It is submitted that such a conclusion is both proper and desirable. In practical effect, the logical application of the defendant's election theory as announced in the Brown Materials $\mathrm{Co}$. case would introduce undesirable uncertainty into the law of venue. In an ordinary local-mixed action, for example, plaintiff could not commence his action anywhere with confidence that venue would not

116 Id. at 574,189 P.2d at 551.

11738 Cal. 2d 28, 237 P.2d 265 (1951), 25 So. CaLIF. L. REv. 491 (1952).

11838 Cal. 2d 28, 33, 34, 237 P.2d 265, 267, 268 (1951), 25 So. CaIr. I. Rev. 491 (1952).

119132 Cal. App. 2d 354, 282 P.2d 201 (1955).

120 The court regarded the alternative venue choices provided by CAx. Const. art. XII, $\S 16$, as privileges granted to a plaintiff and not rights which could be asserted by a corporate defendant. Accord, Strassburger v. Santa Fe Land Improvement Co., 54 Cal. App. 7, 200 Pac. 1065 (1921).

121 In this respect the opinion seems equally applicable to individual defendants since the alternative venue choices authorized by CAL. CoDE Crv. Proc. $\S 395$ in certain tort and contract cases are also regarded as a plaintiff's privilege and not a defendant's right. See Goossen v. Clifton, 75 Cal. App. 2d 44, 170 P.2d 104 (1946); Martinez v. Martinez, 99 Cal. App. 2d 425, 221 P. $2 d 986$ (1950). 
be changed. If begun in either the realty-situs or the residence county, defendant could insist upon transfer to the other. If plaintiff began a transitory-mixed action upon joined contract and personal injury counts in the county where the contract was entered into, defendant could have venue changed to the county where the injury occurred; and if commenced in the latter county, could insist upon transfer to the former.

Even as limited by Neet $v$. Holmes, ${ }^{122}$ the defendant's election theory permits a defendant to supersede the plaintiff's selection of improper venue with equally improper venue. In a local-mixed action, for example, defendant may successfully move to transfer to the realty-situs county if commenced in a "neutral" county; and yet if the same action were commenced in the former county he may with equal success move to transfer to his residence county upon the same "wrong court" grounds. The reason why a defendant thus should be permitted to insist upon theoretically improper venue at the expense of the plaintiff is not apparent.

These anomalies of the defendant's election theory are difficult if not impossible to reconcile with section 398 of the Code of Civil Procedure. That section only authorizes a transfer of venue to "a court ... designated as a proper court . . by the provisions of this title ...." In If in the last example given above the realty-situs county is a "proper" one to which defendant may move for a change of venue, it would seem to be an equally "proper" place in which to lay venue initially; yet the cases are uniformly to the contrary. ${ }^{124}$ If the realty-situs county is not "proper," defendant's motion to transfer there should be denied; yet the defendant's election theory leads to the contrary result. The theory, it is submitted, is inherently unsound and should be rejected.

The defendant's right theory has the advantage of simplicity, but at the expense of completeness. As indicated by question marks in the Appendices, this theory is devoid of doctrinal guides to reliable solution of significant types of venue problems arising in mixed actions begun in a "neutral" county. In part, such inadequacy flows from the fact that "defendant's right" is essentially a negative approach. It provides a firm theoretical basis for denying the propriety of venue as laid, but it merely assumes the mevitable propriety of the defendant's residence venue to the exclusion of other possibilities. In the local-mixed action cases, however, it is by no means apparent as a matter of statutory interpretation why residence venue is any more "proper" than realty-situs venue. The defendant's right theory attempts to meet this difficulty by a further assumption of a hierarchy of venue pohicy: Statutory venue elsewhere is subordinate to de-

\footnotetext{
$12219 \mathrm{Cal} .2 \mathrm{~d} 605,122$ P.2d 557 (1942), discussed in text at note 110 supra.

123 Cal. Code Crv. Proc. $\$ 398$. (Emphasis added.)

124 Cases cited note 54 supra.
} 
fendant's right to venue at his residence which is an "ancient and valuable"125 and hence "important"126 and a "fundamental"122 right to be protected. ${ }^{128}$ Although this assumption appears to be unsupported in fact, ${ }^{129}$ it at least contributes partial doctrinal justification for what would otherwise seem to be a forced interpretation of section 398, thereby giving content and direction to the application of the defendant's right theory.

The exclusive exception theory, on the other hand, has the virtue of providing a logical resolution of the conflict between what appear to be equally appicable inconsistent venue provisions and the insistence of section 398 upon transfer to a "proper county" for the trial of the entire action. The answer under this theory is simple. If the action is a mixed one, only a defendant's residence county is proper. It is submitted that this solution seems altogether too mechanical in its application and leads to results which are obviously not in accord with the legislative venue pattern. For example, let us assume a contract cause of action, properly triable in county $\mathrm{A}$ because the contract was made there; a personal injury cause of action, properly triable in county $A$ because the injury occurred there; and a real property cause of action, properly triable in county $A$ because the land is located there. It would appear hardly consistent with legislative intent to hold upon joinder of all or any two of these causes that county $A$ no longer is proper venue and that the county of defendant's residence becomes the only proper place of trial. Yet despite the fact that in such joined action the particular venue requirements applicable to each count have been fully satisfied, the "exclusive exception" rationale appears to require precisely that holding.

${ }^{125}$ See Deas v. Lido Lumber Co., 132 Cal. App. 2d 402, 282 P.2d 90 (1955); Benjamin v. Benjamin, 128 Cal. App. 2d 367, 275 P.2d 43 (1954); Kaluzok v. Brisson, 27 Cal. 2d 760, 167 P.2d 481 (1946); Lyons v. Brunswick-Balke-Collender Co., 20 Cal. 2d 579, 127 P.2d 924 (1942); Brown v. Happy Valley Fruit Growers, 206 Cal. 515, 274 Pac. 977 (1929).

126 See Goossen v. Clifton, 75 Cal. App. 2d 44, 170 P.2d 104 (1946).

127 See Bybee v. Fairchild, 75 Cal. App. 2d 35, 170 P.2d 54 (1946).

128 Application of this reasoning to local-mixed actions may be unsound. It appears that section 5 of article VI was added to the Constitution of 1879 to ensure to defendants the riglt to venue in certain real property actions, especially mortgage foreclosures, in the realty-situs county rather than elsewhere. 3 Debates and Proceedings of tere Constitutionat ConvenTION 1334 (1881). Moreover, realty-situs venue under CAL. CODE Crv. Proc. $\$ 392$ has been referred to hoth as a plaintiff's privilege, Chew v. Storrie, 108 Cal. App. 313, 291 Pac. 610 (1930), and as a defendant's right, Standard Brands of California v. Bryce, 1 Cal. 2d 718, 37 P.2d 446 (1934).

129 The earbest California legislatures evidently did not regard defendant's residence venue as an unusually valuable or fundamental right. The original Practice Act of 1850 , for example, in a provision which is the predecessor of the present $\$ 395$, authorized venue in "all other cases" in the county "in which the parties, or any of them [including either plaintiff or defendant] ... reside ... ." Cal. Stat. 1849-50, c. 142, \& 20. (Emphasis added.) The word "parties" was not changed to "defendants" until 1858. Cal. Stat. 1858, c. 103, §1.

At common law venue was predominantly where the cause of action arose rather than at defendant's residence. See Blume, Place of Trial of Civil Cases, 48 MrCH. L. Rev. 1 (1949). 


\section{A RECONCILIATORY PROPOSAI}

Undeniably, the exclusive exception and defendant's right theories contain meritorious elements. In many, if not all, of the cases in which either theory has been judicially invoked to justify a given result the same result would have obtained under the other. The most striking inconsistencies between them are still largely potential. The areas of mutual consistency suggest the possibility of reconciling the cases by formulation of a new rule based upon the strengths but eliminating the weaknesses of both theories. A desirable reconciliation would thus combine the simplicity of the defendant's right theory without its internal contradictions and the certainty of the exclusive exception theory without its inflexibility.

Preliminarily, it is suggested that the key to resolution of mixed action venue problems is found in the previously referred to fact that section 398 of the Code of Civil Procedure clearly hypothesizes an ascertainable "proper county" for the trial of every action. That section authorizes a change of venue only when the action has been commenced "in a court, other than one designated as a proper court for the trial thereof," and requires that the change be to "any such proper court in a proper county ...." In the face of this clear legislative insistence that there is a "proper" county for the trial of every action, ${ }^{130}$ it would seem to follow that any rule for solving mixed action venue problems should satisfy two basic standards: First, in recognition of the premise that venue is a matter of legislative policy, it should define as "proper" any-but only such-county or counties as to which the legislative venue policy is satisfied with respect to all counts and all parties; second, since the code appears to contemplate that every defendant has a right to insist upon trial in a "proper" county, the rule should provide that whenever venue is not laid by plaintiff in a "proper" county, as so defined, a change will be granted on motion of any bona fide defendant but only to a county which is "proper." In short, in a mixed action, just as in the simple one-count complaint case, venue should either be proper or improper as to the entire action without any of the intermediate possibilities which have marred the defendant's right theory. At the same time, the criteria for determining a "proper" county should be free from the purely artificial barriers which under the exclusive exception rationale often tend to frustrate rather than effectuate legislative policy.

The following rule, prepared in the form of a new section 398a to be added to the Code of Civil Procedure, is submitted as one which meets the

130 Discussion of the interpretative difficulties involved in determining the proper court within the proper county, where a mixed action is within municipal or justice court jurisdiction, is beyond the scope of the present subject. The dearth of cases in point suggest that such problems are not likely to be grist for appellate litigation. 
foregoing standards and yet, to a large extent, reconciles the actual decisions in the numerous mixed action cases:

$\S 398 \mathrm{a}$. If an action is commenced upon two or more causes of action or against two or more defendants, or both, in a county other than one designated by the provisions of this title or of the constitution as a proper court for the trial thereof with respect to each count and each defendant, considered separately, it must be transferred on proper and timely motion to any such proper court, agreed to, designated, or determined in the manner provided in section 398. If there is no county which is proper for trial with respect to each count and each defendant, considered separately, the action inust be transferred for trial to a county in which the defendants, or some of them, resided at the commencement of the action.

The proposed rule, it will be noted, has two parts. First, it requires a change of venue only when plaintiff's choice of place of trial is improper as to one of the counts or one of the defendants. The rule thus precludes transfer when venue is independently proper as to each count irrespective of the nature of the cause of action or the code section governing its venue. For example, the rule would lead to demal of a change of venue of a local-mixed action involving joined contract and realty counts brought in the county where the contract was inade and land located. It likewise would preclude change of venue of a corporation-mixed action brought in the county of the corporation's principal place of business, or in any other county equally proper as to both defendants, such as the county where the contract sued on was made or was to be performed according to its express terms, or the county where the injury to plaintiff or plaintiff's personal property took place.

Second, it either postulates or provides for the existence of at least one ascertainable county which is always proper as to all counts and all parties. In a local-mixed action this proper county will often be the defendant's residence county but it will be the county where the land is situated if the transitory count is independently triable there. ${ }^{131} \mathrm{~A}$ transitory-mixed or corporation-mixed action likewise would not inevitably have to be tried at a defendant's residence but would be triable in any other county which is proper as to each count and each defendant considered separately. The defendant would have kis election between such alternatives as might be appropriate, of course, but only where the plaintiff mitially had failed to lay venue in one of the available proper counties.

131 The interpretative analysis underlying the exclusive exception theory is accepted as a sound basis for providing that a local-mixed action is in effect governed, as to venue, by the "all other cases" clause of Cad. CODE Crv. Proc. $\$ 395$ whenever the realty-situs county is not independently proper as to the transitory count. Where venue is independently proper in a non-residence county as to each of the joined counts, however, no reason exists why the action should be regarded solely as one of the "other cases" referred to in $\S 395$, and, indeed, to do so would tend to frustrate the legislative venue policy. 
It is believed that the proposal here made would justify the result already reached in most of the decided cases, insofar as the facts disclosed in the opinions therem would seem to indicate. It provides for uniformity, simplicity, and accuracy of application; eliminates the anomalous theoretical connotations inherent in existing theories; and more closely approximates conformity in all cases to the expressed intent of the venue provisions of code and constitution, thereby striking a better balance between the venue rights of plaintiffs and defendants.

Application of the proposal, and a comparison with the existing three theories, is illustrated in Appendices A, B, and C by the column headed "Proposed New Rule." It will be observed that im each hypothetical situation indicated the proposed rule would lead to trial in a "common denominator" county-that is, a county which would be proper venue for each count and each defendant considered separately.

Few will deny the need for new paths to the solution of mixed action venue problems. The tendency to repeated prolonged litigation of such purely procedural issues does little to advance the stature of the law. It is beheved that the proposal here offered, if adopted, may assist in reducing that tendency.

\section{APPENDIX A}

$P$ is suing $D$ on two joined causes of action:

a) to enforce a contract obligation for payment of money,

b) to recover damages for injury to Blackacre.

Blackacre is located in County 1. D resides in County 2. The contract was entered into in County 3 , and contains a written agreement for performance in County 1.

\begin{tabular}{|c|c|c|c|c|c|}
\hline \multirow[b]{2}{*}{$\begin{array}{l}\text { If } P \text { begins the } \\
\text { action in }\end{array}$} & \multirow{2}{*}{$\begin{array}{l}\text { and } D \text { moves } \\
\text { to change } \\
\text { venue to } \\
\text { county }\end{array}$} & \multicolumn{4}{|c|}{ the court's ruling should be as follows: } \\
\hline & & $\begin{array}{c}\text { Exclusive } \\
\text { exception } \\
\text { theory }\end{array}$ & $\begin{array}{c}\text { Defendant's } \\
\text { right } \\
\text { theory }\end{array}$ & $\begin{array}{l}\text { Defendant's } \\
\text { election } \\
\text { theory }\end{array}$ & $\begin{array}{l}\text { Proposed } \\
\text { new } \\
\text { rule }\end{array}$ \\
\hline County 1 & $\begin{array}{l}2 \\
3\end{array}$ & $\begin{array}{l}\text { GRANT (a) } \\
\text { deny (b) }\end{array}$ & $\begin{array}{l}\operatorname{deny}(c) \\
\operatorname{deny}(c)\end{array}$ & $\begin{array}{l}\text { deny }(c) \\
\text { deny }(c)\end{array}$ & $\begin{array}{l}\text { deny }(c) \\
\text { deny }(c)\end{array}$ \\
\hline County 2 & $\begin{array}{l}1 \\
3\end{array}$ & $\begin{array}{l}\text { deny }(c) \\
\text { deny }(c)\end{array}$ & $\begin{array}{l}\text { deny }(c) \\
\operatorname{deny}(c)\end{array}$ & $\begin{array}{l}\text { GRANT (d) } \\
\text { deny (e) }\end{array}$ & $\begin{array}{c}\text { GRANT (a) } \\
\text { deny (b) }\end{array}$ \\
\hline County 3 & $\begin{array}{l}1 \\
2\end{array}$ & $\begin{array}{c}\text { deny (b) } \\
\text { GRANT (a) }\end{array}$ & $\begin{array}{c}P(f) \\
\text { deny }(e)\end{array}$ & $\begin{array}{l}\text { GRANT (d) } \\
\text { deny (e) }\end{array}$ & $\begin{array}{c}\text { GRANT (a) } \\
\text { deny (b) }\end{array}$ \\
\hline $\begin{array}{l}\text { A "neutral" } \\
\text { county }\end{array}$ & $\begin{array}{l}1 \\
2 \\
3\end{array}$ & $\begin{array}{c}\text { deny (b) } \\
\text { GRANT (a) } \\
\text { deny (b) }\end{array}$ & $\begin{array}{c}?(\mathbf{f}) \\
\text { GRANT (a) } \\
\text { deny (b) }\end{array}$ & $\begin{array}{l}\text { GRANT (a) } \\
\text { GRANT (d) } \\
\text { GRANT (d) }\end{array}$ & $\begin{array}{c}\text { GRANT (a) } \\
\text { deny (b) } \\
\text { deny (b) }\end{array}$ \\
\hline
\end{tabular}




\section{EXPLANATORY NOTES}

(a) Venue is presently improper under this theory but would be proper in the transferee county designated by the motion.

(b) Venue is presently improper, but the transferee county designated would be equally improper.

(c) Venue is presently proper under this theory.

(d) Venue is presently improper as to at least one count, thus justifying transfer to a county proper as to that count.

(e) The transferee county designated in the motion is proper alternative venue only with respect to the contract count; but since venue is presently proper as to that count, defendant has no standing to claim that by reason of the joinder he has been deprived of any right to venue in the designated transferee county.

(f) Question marks indicate a lack of theoretical development sufficient to support a rehable prediction.

\section{APPENDIX B}

$P$ is suing $D$ on two joined transitory causes of action:

a) for breach of contract,

b) for injury to personal property.

The injury occurred in County $1 . \mathrm{D}$ resides in County 2 . The contract was entered into in County 3 , and contains a written agreement for performance in County 1.

\begin{tabular}{|c|c|c|c|c|c|}
\hline \multirow[b]{2}{*}{$\begin{array}{l}\text { If } P \text { begins the } \\
\text { action in }\end{array}$} & \multirow{2}{*}{$\begin{array}{l}\text { and } D \text { moves } \\
\text { to change } \\
\text { venue to } \\
\text { county }\end{array}$} & \multicolumn{4}{|c|}{ the court's ruling should be as follows: } \\
\hline & & $\begin{array}{c}\text { Exclussive } \\
\text { exception } \\
\text { theory }\end{array}$ & $\begin{array}{c}\text { Defendant's } \\
\text { right } \\
\text { theory }\end{array}$ & $\begin{array}{c}\text { Defendant's } \\
\text { election } \\
\text { theory }\end{array}$ & $\begin{array}{l}\text { Proposed } \\
\text { new } \\
\text { rule }\end{array}$ \\
\hline County 1 & $\begin{array}{l}2 \\
3\end{array}$ & $\begin{array}{l}\text { GRANT (a) } \\
\text { deny (b) }\end{array}$ & $\begin{array}{l}\text { deny (c) } \\
\text { deny (c) }\end{array}$ & $\begin{array}{l}\text { deny (c) } \\
\text { deny (c) }\end{array}$ & $\begin{array}{l}\text { deny (c) } \\
\text { deny (c) }\end{array}$ \\
\hline County 2 & $\begin{array}{l}1 \\
3\end{array}$ & $\begin{array}{l}\text { deny (c) } \\
\text { deny (c) }\end{array}$ & $\begin{array}{l}\text { deny (c) } \\
\text { deny (c) }\end{array}$ & $\begin{array}{l}\text { deny (c) } \\
\text { deny (c) }\end{array}$ & $\begin{array}{l}\text { deny (c) } \\
\text { deny (c) }\end{array}$ \\
\hline County 3 & $\begin{array}{l}1 \\
2\end{array}$ & $\begin{array}{c}\text { deny (b) } \\
\text { GRANT (a) }\end{array}$ & $\begin{array}{c}\text { ? (f) } \\
\text { GRANT (a) }\end{array}$ & $\begin{array}{l}\text { GRANT (d) } \\
\text { GRANT (d) }\end{array}$ & $\begin{array}{l}\text { GRANT (a) } \\
\text { GRANT (a) }\end{array}$ \\
\hline $\begin{array}{l}\text { A "neutral" } \\
\text { county }\end{array}$ & $\begin{array}{l}1 \\
2 \\
3\end{array}$ & $\begin{array}{c}\text { deny (b) } \\
\text { GRANT (a) } \\
\text { deny (b) }\end{array}$ & $\begin{array}{c}\text { ? (f) } \\
\text { GRANT (a) } \\
\text { deny (b) }\end{array}$ & $\begin{array}{l}\text { GRANT (a) } \\
\text { GRANT (a) } \\
\text { GRANT (d) }\end{array}$ & $\begin{array}{c}\text { GRANT (a) } \\
\text { GRANT (a) } \\
\text { deny (b) }\end{array}$ \\
\hline
\end{tabular}

\section{EXPLANATORY NOTES}

(a) Venue is presently improper under this theory but would be proper in the transferee county designated by the motion.

(b) Venue is presently improper, but the transferee county designated would be equally improper.

(c) Venue is presently proper under this theory. 
(d) Venue is presently improper as to at least one count, thus justifying transfer to a county proper as to that count.

(f) Question marks indicate a lack of theoretical development sufficient to support a reliable prediction.

\section{APPENDIX C}

$\mathrm{P}$ is suing on a contract cause of action, naming CORP and D as defendants.

The contract was entered into in County 1 . It was orally agreed to be performable in County 2 and was breached there. CORP has its principal place of business and D resides in County 3 .

\begin{tabular}{|c|c|c|c|c|c|c|}
\hline \multirow[b]{2}{*}{$\begin{array}{l}\text { If } P \text { begins } \\
\text { the action } \\
\text { in County }\end{array}$} & \multirow[b]{2}{*}{$\begin{array}{l}\text { and a mo- } \\
\text { tion is } \\
\text { made by }\end{array}$} & \multirow[b]{2}{*}{$\begin{array}{l}\text { to change } \\
\text { venue to } \\
\text { County }\end{array}$} & \multicolumn{4}{|c|}{ the court's ruling should be as follows: } \\
\hline & & & $\begin{array}{l}\text { Exclusive } \\
\text { exception } \\
\text { theory }\end{array}$ & $\begin{array}{l}\text { Defendant's } \\
\text { right } \\
\text { theory }\end{array}$ & $\begin{array}{c}\text { Defendant's } \\
\text { election } \\
\text { theory }\end{array}$ & $\begin{array}{l}\text { Proposed } \\
\text { new } \\
\text { rule }\end{array}$ \\
\hline 1 & $\mathrm{D}$ & $\begin{array}{l}2 \\
3\end{array}$ & $\begin{array}{c}\text { deny (a) } \\
\text { GRANT (b) }\end{array}$ & $\begin{array}{l}\text { deny (c) } \\
\text { deny (c) }\end{array}$ & $\begin{array}{l}\text { deny (c) } \\
\text { deny (c) }\end{array}$ & $\begin{array}{l}\text { deny (c) } \\
\text { deny (c) }\end{array}$ \\
\hline 1 & CORP & $\begin{array}{l}2 \\
3\end{array}$ & $\begin{array}{c}\text { deny (a) } \\
\operatorname{GRANT}(b)\end{array}$ & $\begin{array}{l}\text { deny }(c) \\
\text { deny }(c)\end{array}$ & $\begin{array}{l}\text { deny }(c) \\
\text { deny }(c)\end{array}$ & $\begin{array}{l}\text { deny }(c) \\
\text { deny }(c)\end{array}$ \\
\hline 2 & $\mathrm{D}$ & $\begin{array}{l}1 \\
3\end{array}$ & $\begin{array}{c}\text { deny (a) } \\
\text { GRANT (b) }\end{array}$ & $\begin{array}{c}?(\mathfrak{l}) \\
\text { GRANT (b) }\end{array}$ & $\begin{array}{l}\text { GRANT (b) } \\
\text { GRANT (b) }\end{array}$ & $\begin{array}{l}\text { GRANT (b) } \\
\text { GRANT (b) }\end{array}$ \\
\hline 2 & CORP & $\begin{array}{l}1 \\
3\end{array}$ & $\begin{array}{c}\text { deny (a) } \\
\text { GRANT (b) }\end{array}$ & $\begin{array}{l}\text { deny (d) } \\
\text { deny (d) }\end{array}$ & $\begin{array}{l}\text { deny (d) } \\
\text { deny (d) }\end{array}$ & $\begin{array}{l}\text { GRANT (b) } \\
\text { GRANT (b) }\end{array}$ \\
\hline $\begin{array}{l}\text { A "neutral" } \\
\text { county }\end{array}$ & $\mathrm{D}$ & $\begin{array}{l}1 \\
2 \\
3\end{array}$ & $\begin{array}{c}\text { deny (a) } \\
\text { deny (a) } \\
\text { GRANT (b) }\end{array}$ & $\begin{array}{c}?(f) \\
\text { deny (a) } \\
\text { GRANT (b) }\end{array}$ & $\begin{array}{l}\text { GRANT (b) } \\
\text { deny (a) } \\
\text { GRANT (b) }\end{array}$ & $\begin{array}{l}\text { GRANT (b) } \\
\text { deny }(\mathrm{a}) \\
\text { GRANT (b) }\end{array}$ \\
\hline $\begin{array}{l}\text { A "neutral" } \\
\text { county }\end{array}$ & CORP & $\begin{array}{l}1 \\
2 \\
3\end{array}$ & $\begin{array}{c}\text { deny (a) } \\
\text { deny (a) } \\
\text { GRANT (b) }\end{array}$ & $\begin{array}{c}?(f) \\
?(f) \\
\text { GRANT (b) }\end{array}$ & $\begin{array}{l}\text { GRANT (b) } \\
\text { GRANT (b) } \\
\text { GRANT (b) }\end{array}$ & $\begin{array}{l}\text { GRANT (b) } \\
\text { deny (a) } \\
\text { GRANT (b) }\end{array}$ \\
\hline
\end{tabular}

EXPLANATORY NOTES

(a) Venue is presently improper, but the transferee county designated is equally improper under this theory.

(b) Venue is presently improper under this theory but would be proper in the county designated by the motion.

(c) Venue is presently proper as to both parties.

(d) Venue is presently proper as to the corporation, even though improper as to $\mathrm{D}$, and hence CORP cannot object.

(f) Question marks indicate a lack of theoretical development sufficient to support a reliable prediction. 


\section{California Law Review}

MEMIBER NATIONAL AND WESTERN CONFERENCES OF LAW REVIEWS

Published Five Times Yearly by Students of the School of Law of the University of California, Berkeley, California. Indexed in Index to Legal Periodicals and Public Affairs Information Service.

\section{BOARD OF EDITORS}

Donato M. Cahen Editor

Wallace R. Peck

Assistant Editor

WITIIAMY R. BERKMIAN

Managing Editor

Book Review Editor

GERALD R. KNECHT

ROBERT O. NAGLE

ROBERT A. SELTGSON

W. P. Clancey, Jr.

BIIIT H. HuNT

Donatd L. KIng

MarseaII W. KraUSE
JOE J. Y YSAKI

Revising Editors

Marc H. Mongetsrer

Article Edïtor

JohN E. Sparks

Stanton G. Ware

Associate Editors

Harold E. LANDIS

RICEARD T. LEMMMOX

WIIIJAMr O. MrNOR

MARIIYN MitcheLI

General Secretary

\section{Contributors}

ROGER J. NICHOLS

JAMES F. KIRERAM 